\title{
Ownership and inequalities: exploring UNEP's Environmental Cooperation for Peacebuilding Program
}

\author{
Florian Krampe ${ }^{1}[\mathbb{D}$
}

Received: 20 August 2020 / Accepted: 2 February 2021 / Published online: 18 February 2021

(c) The Author(s) 2021

\begin{abstract}
The question of ownership — that is, who is included and excluded from policy processes- has become one of the most pressing issues in the global discourse on peace and conflict. While research shows that the inclusion of domestic actors is critical to success, broader international processes often neglect these actors. Focused on environmental peacebuilding-the sustainable management of natural resources in post-conflict settings - as an emerging area, this article employs qualitative content analysis (QCA) to study four core reports of the United Nations Environment Programme (UNEP)'s Environmental Cooperation for Peacebuilding Programme (2008-2015). The results reveal that the framing of environmental peacebuilding in these documents contributes to power inequalities being reinforced. The reports' language suggests that, overall, UNEP favors international ownership of environmental peacebuilding. By contrast, local actors-both state and non-state-appear to be considered a risk in the context of natural resource management. This article discusses the implications of this lack of inclusion for peacebuilding practice.
\end{abstract}

Keywords United Nations Environment Programme · Ownership · Environmental peacebuilding · Qualitative content analysis

\section{Introduction}

Over the past two decades, increased scholarly attention has been brought to bear on the role of natural resources, both as a cause of conflict (Collier and Hoeffler 2000; Le Billon 2001) and a means of building peace (Johnson et al. 2021; Conca and Dabelko 2002; Ide 2018; Krampe and Swain 2021). The latter has become known as environmental peacebuilding. While the field has grown tremendously over the past decade, scientific knowledge remains fragmented and has mostly been focused on finding empirical examples to provide proof of concept (Krampe 2017). Critical studies examining the potential adverse effects of environmental interventions are only slowly emerging (Johnson et al. 2021;

Handled by Ayyoob Sharifi, Hiroshima University IDEC Higashi Hiroshima, Japan.

Florian Krampe

florian.krampe@sipri.org

1 Stockholm International Peace Research Institute (SIPRI), Stockholm, Sweden
Dabelko et al. 2013; Krampe et al. 2018; Ide 2020), as are studies interrogating the normative underpinnings of the concept (Mason 2014; Maertens 2018). Understanding the effects of environmental peacebuilding's normative content is important for the study of the sustainability-peace nexus, as it helps in furthering the conception of peace as 'a broad and inclusive concept that goes beyond just the absence of war and conflict and pursues social harmony and justice' (Virji et al. 2019).

This article contributes to discussions of ownership in the design and implementation of United Nations Environment Programme (UNEP) security policies within peacebuilding processes. The focus is on four core reports produced by UNEP's Environmental Cooperation for Peacebuilding Programme (2008-2015) —one of four workstreams under UNEP's Post-Conflict and Disaster Management Branch (PCDMB). Using qualitative content analysis (QCA), the article examines ownership frames within these documents-that is, key messages indicating which actors are included and excluded from policy processes. The findings suggest that the policy design and implementation of UNEP's security agenda depends heavily on international 
state actors. While it is predictable that UNEP — known for its focus on information provision-relies on international expert knowledge, what is perhaps surprising is the lack of recognition for international non-state actors. Moreover, this exclusion of domestic actors aligns with a concerning trend across the documents: a strong negative portrayal of domestic state and non-state actors. This has potentially significant implications for the implementation of these policies.

The article is structured in seven parts. Following this introduction, section two outlines the literature on actors and ownership in environmental peacebuilding. Section three then sets out the study's analytical framework by showing how policy frameworks emerge, as well as how assumptions about ownership of global governance processes provide important insights into the power and influence of involved actors. The section also outlines how such processes are operationalized. Section four describes the methodological approach of QCA, while section five reveals the results of this approach when applied to UNEP's policy reports. Section six discusses the implications arising from these results before the article concludes by commenting on policy implications and potential pathways for future research.

\section{Actors and ownership in environmental peacebuilding}

At the center of the concept of ownership are actors, and the relationships between them. The majority of peacebuilding scholarship tends to categorize actors into two distinct groups: international and local. This vertical distinction between the two groups of actors is important, as it signals a power asymmetry (Jarstad and Olsson 2012). Even so, the distinction does not differentiate between types of actor within the two categories-something that is particularly clear at the local level. Research focused on Security Sector Reform understands local actors to be 'those institutions authorised to use or threaten force' (Donais 2008, p. 5). However, depending on the relevant policy, 'the local' can be either a state or non-state actor. To capture such variation, researchers have more recently favored actor-oriented approaches, which move 'beyond the broad categories of conflict between the local and the global' (Höglund and Orjuela 2013, p. 300). Essentially, an actor-oriented framework overcomes the structuralist simplification that can be traced back to Talcott Parson's work on social systems. Parson's social systems, along with many subsequent studies on peacebuilding, have inadvertently treated state and society as the same social system (Migdal 2004, p. 4). The consequence of this conflation, as Migdal argues, is that it potentially favors 'a singular set of social values and norms, which he [Parson] asserts were internalized by society's members' (Migdal 2001, p. 5). An actor-oriented approach

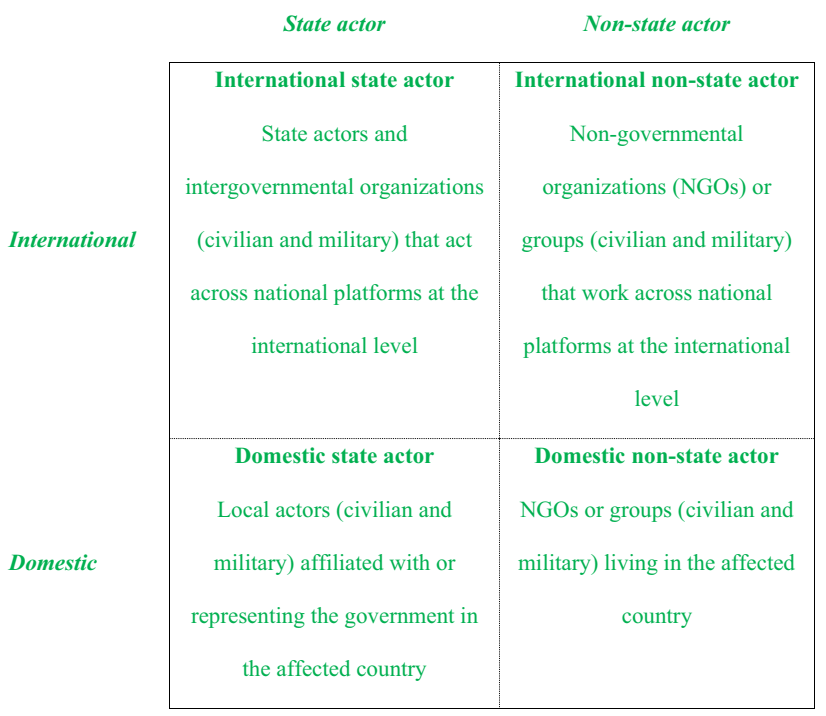

Fig. 1 Matrix of actor groups, adapted from Krampe and Ekman (2020)

instead disaggregates post-conflict actors, thereby allowing for a plurality of values and norms. Thus, there is a vertical distinction between domestic and international actors, as well as a horizontal one between domestic state and nonstate actors (Krampe and Ekman 2020) (see Fig. 1).

Given environmental peacebuilding's focus on promoting sustainable natural resource management in post-war countries, it would be reasonable to expect that non-state actors play a relevant role in policy frameworks. This is because non-state actors have the ability to change environmental norms and influence the environmental policies of other actors, including states. Inclusion of domestic and international non-state actors into peacebuilding processes is, therefore, considered a pathway to sustainable natural resource management. Moreover, this pathway appears particularly promising from the point of view of UNEP's environmental peacebuilding policy framework, as the UN has often emphasized the role and status of non-state actors on the international stage (Albin 1999; Chesterman 2007).

Indeed, both the peacebuilding (Paffenholz 2010; Barma 2016; Campbell 2019) and environmental governance literature (Haas et al. 1993; Park 2005; Susskind and Ali 2014; Murdie and Urpelainen 2015; Roger and Dauvergne 2016) at the intersection of which the environmental peacebuilding literature sits-stress the importance of interaction with and ownership by non-state actors. In particular, the hope is that a strong civil society has 'the potential to make a more locally resonant and sustainable form of peace' (Richmond 2013, p. 396). EcoPeace Middle East is just one example of an environmental peacebuilding project that emphasizes the 
role domestic non-state actors can play in facilitating environmental cooperation (Conca 2015, pp. 212-213).

However, while we might expect non-state actors to enjoy a higher degree of ownership, the emerging environmental peacebuilding literature in fact suggests that questions of ownership are often problematic and can potentially undermine peace outcomes. One stream of work stresses that environmental peacebuilding approaches tend to overemphasize technical solutions and so depoliticize the issues faced, thereby ignoring the highly political reality, especially in local contexts (Aggestam 2015; Krampe 2016; Ide 2020). Others have demonstrated that it is transnational networks, rather than domestic actors, that have been strengthened (Johnson 2019), while others again have pointed to the tensions that emerge between peacekeeping actors and local populations around natural resources (UNEP 2012; Maertens 2018). In sum, the research indicates that, to better understand why this discrepancy between expectation and reality exists, further investigation into questions of ownership within environmental peacebuilding is merited. The question, then, is how can we empirically examine non-state roles? Moreover, can we understand the ways - and the reasons why-non-state actors are or are not being engaged as meaningful partners? In answering these questions, this article builds on an understanding of ownership that has been critical to uncovering the inherently normative dimension of 'liberal' peacebuilding.

Given the narrow focus on four UNEP policy reports, this research does not purport to be exhaustive. Other researchwhich lies beyond the scope of this study-has provided important insights into the wider normative setup of global environmental politics (Gemmill and Bamidele-Izu 2002; Najam 2003; O’Neill et al. 2004; Ivanova 2010; Bernauer et al. 2013; Conca 2015). By contrast, this study aims for a more specific contribution through analysis of some of the key documents shaping the current state of environmental peacebuilding (Krampe 2017, pp. 3-5; Krampe and Swain 2021). In doing so, the research offers important insights for UNEP's future policy work on environmental peacebuilding, as well as shedding light on what might be the best pathway toward a more sustainable global society.

\section{Analytical framework: ownership in global governance}

To empirically study the roles ascribed to actors in the UNEP Environmental Cooperation for Peacebuilding Programme reports, I focus on operationalization policy frames-that is, the main message of the policy framework-in relation to ownership. Previous research has demonstrated the importance of studying the content of important policy documents to better understand not only environmental peacebuilding processes but their normative content (e.g. Conca 2015; Kovach and Conca 2016).

As Wendt argues, 'actors need to define the situation before they can choose a course of action' (Wendt 1999, p. 186). In the process of creating a policy framework to guide future decision-making, international actors draw on seemingly objective scientific knowledge, as well as ideational factors, such as their beliefs and interests (Jasanoff 2004). These ideational factors become part of policy frameworks as 'collective, intersubjective understandings' (Autesserre 2009, p. 250). Policy frames and the comprehensive frameworks built upon them, not only shape the decision-making processes of a particular organization, institution or actor but tend to spread within larger communities of actors. The spread of policy frameworks is facilitated by, first, the organizational platforms where they were originally established, which are typically state actors on the international stage, such as the UN, World Bank or UNEP (Finnemore and Sikkink 1998). Second, ensuring a policy frame resonates with a variety of interest groups and people helps anchor the framework - and any explicit or implicit messages contained therein — within the international arena. In other words, if a message uses clear, direct language and simplified causal logic, while also offering ideal solutions and policies, it is more likely to be included in policy frameworks.

The psychological explanation for this is that policy frames help construct cognitive frames, which in turn inform actors' decision-making processes (Haas 1992; Finnemore and Sikkink 1998). Further, policy frames can be effectively disseminated through professional training, which is designed to influence and (re)shape participants' values and worldviews (Finnemore 2006, p. 143). Within peacebuilding, policy frames have been found to exert a powerful influence on the practices of peacebuilders in the field (Coles 2011; Autesserre 2014).

In addition to explicit policy frames, policy documents contain implicit frames indicating who is expected to design and implement policies - that is, messages about ownership of governance processes. To make this implicit content visible, I use the concept of ownership. ${ }^{1}$ As mentioned above, many scholars and practitioners consider domestic ownership an essential element of successful peacebuilding. However, rather than using the concept to highlight and romanticize domestic and local actors, ownership is here used to help uncover which actors are perceived to exert influence on

\footnotetext{
1 There is an extensive academic debate on local ownership in peacebuilding. In this section, rather than presenting an extended review of this debate, I focus solely on developing indicators to capture and study different forms of ownership. For more insight on the broader debate, see Donais (2012), Lee and Özerdem (2015) and von Billerbeck (2015).
} 
international peacebuilding interventions, and which actors are excluded.

\section{Operationalizing actors}

For the purposes of this article, ownership is understood to consist of two ideal types: domestic and international. This means ownership is first and foremost distinguished vertically between international and domestic actors, who either do or do not hold ownership of a process. Yet, given the complexity of actors in the international system, there is good reason to further disaggregate actors horizontally between state and non-state actors.

This results in actors being grouped into four ideal types (see Fig. 1), which has a number of advantages, enabling: (1) a more nuanced disaggregation of actors in peacebuilding, without falling into the trap of relativism or reductionism; (2) a focus on state-society relationships, and their perceived legitimacy; and (3) a more nuanced visualization of ownership. The dotted lines separating the four groups in Fig. 1 indicate that while they are conceived of as ideal types, in practice categories overlap. UNEP and the UN fall into both the category of an international state actor and-as international NGOs - the category of an international non-state actor. Nonetheless, this categorization has obvious limitations, as it places distinctly different types of the actor within the same category. This shortcoming is, however, compensated for by the qualitative approach of this study. Usually, it is clear which actor is being described, thereby allowing for actors to be differentiated and qualifying the reader's understanding of the created boundaries (see Mitchell 1991).

\section{Operationalizing policy frames indicating ownership}

To investigate how and why non-state actors are or are not being engaged as meaningful partners in UNEP environmental peacebuilding practice, I derive four policy frames that help 'locate' ownership in the studied reports: (1) portrayal of actors; (2) proposed solutions; (3) the kind of knowledge these solutions demand; and (4) who has effective control of implementation processes.

In the peacebuilding literature, there are two ideal types of ownership: domestic ownership and international ownership. The notion of domestic ownership ${ }^{2}$ is rooted in an understanding of peacebuilding as a communitarian, bottomup process (Lederach 1997; Donais 2009). As a concept, domestic ownership emphasizes communities being able to

\footnotetext{
${ }^{2}$ Acknowledging the horizontal difference of actors, I use the term domestic ownership to capture more accurately what has otherwise been labelled local ownership.
}

self-govern in accordance with their cultural identity and heritage, thereby stressing 'the importance of tradition and social context in determining the legitimacy and appropriateness of particular visions of political order, justice, or ethics' (Donais 2009, p. 6). Domestic ownership demands that domestic actors have effective control and agency, or the 'ability to define one's goals and act upon them' (Kabeer 1999, p. 438). This entails 'treating local actors as potential agents of transformation, rather than as objects to be transformed' (Donais 2009, p. 19). Further, domestic ownership emphasizes the reciprocal role of state and society in building peace, as it is the legitimacy of the relationship between these two groups of actors that determines internal peace and stability (Krampe and Ekman 2020; Söderström et al. 2020).

Conversely, Fearon and Laitin argue that international assistance is both required and justified in weak and postwar states. Even if domestically built peace is possible and the most 'natural' pathway to rebuilding a state following the conflict, "the local and international costs and risks of such "natural" processes of state formation can be very high' (Fearon and Laitin 2004, p. 43). Indeed, proponents of international assistance argue that domestic actors have lost credibility as legitimate actors, and lack the capacity or willingness to ensure a transition to peace (Scheye and Peake 2005). Instead, international ownership of peacebuilding processes provides international actors with the authority to define peacebuilding goals and implement the resultant processes on behalf of domestic actors. The explicit goal of such ownership is to build domestic capacity, with the aim of eventually transferring ownership of peace to domestic leaders (Donais 2009). According to this policy frame, international actors typically conceive of domestic ownership as being the product of successful international peacebuilding efforts.

Critiques of international ownership have described capacity-building efforts as acts of imposition, with domestic actors construed as 'objects to be transformed' (Donais 2009, p. 19; see also Chandler 2010, p. 40). For instance, Crawford argues that "the notions of "partnership" and "local ownership", in practice, aim to simultaneously disguise and legitimize the interventions of international agencies in domestic reform processes, serving to mystify power asymmetry' (Crawford 2003, p. 139). Similarly, Chesterman contends that domestic ownership is used figuratively among international actors, as a means of couching agendas in terms of 'locally' defined needs, while in reality control is retained by the international actors (Chesterman 2007).

Along these lines, von Billerbeck argues that UN peacebuilding is shaped by two stereotypes, namely that 'local actors in war-torn countries have weak capacities and that they may be illiberal, divisive, and focused on sectarian gain rather than the common good' (von Billerbeck 2015, p. 299). This framing is important, as the perceived lack of 
Table 1 Coding scheme

\begin{tabular}{|c|c|}
\hline Category & Sub-category \\
\hline \multicolumn{2}{|l|}{ Portrayal of actors } \\
\hline International non-state actors & $\begin{array}{l}\text { Negative } \\
\text { Positive }\end{array}$ \\
\hline International state actors & $\begin{array}{l}\text { Negative } \\
\text { Positive }\end{array}$ \\
\hline Domestic non-state actors & $\begin{array}{l}\text { Negative } \\
\text { Positive }\end{array}$ \\
\hline Domestic state actors & $\begin{array}{l}\text { Negative } \\
\text { Positive }\end{array}$ \\
\hline \multicolumn{2}{|l|}{ Knowledge } \\
\hline Knowledge & $\begin{array}{l}\text { International knowledge } \\
\text { Domestic knowledge }\end{array}$ \\
\hline \multicolumn{2}{|l|}{ Solution } \\
\hline Solutions & $\begin{array}{l}\text { Universal solutions } \\
\text { Contextual and/or } \\
\text { domestic solutions }\end{array}$ \\
\hline \multicolumn{2}{|l|}{ Control } \\
\hline International non-state & $\begin{array}{l}\text { High } \\
\text { Low }\end{array}$ \\
\hline International state & $\begin{array}{l}\text { High } \\
\text { Low }\end{array}$ \\
\hline Domestic non-state & $\begin{array}{l}\text { High } \\
\text { Low }\end{array}$ \\
\hline Domestic state & $\begin{array}{l}\text { High } \\
\text { Low }\end{array}$ \\
\hline
\end{tabular}

domestic capacity motivates how international actors frame their proposed solutions. These solutions are often technocratic and universally applicable, because '[a]s technical issues, they can best be addressed by experts, provided by the international community, and do not require political consultation or debate, as the ends of the policy are not in question' (Zaum 2007, p. 106). This focus on the necessity of international 'expert' knowledge suggests a need to socialize domestic actors, along with their norms and values, into the new 'liberal' post-conflict order (Chandler 2010).

As such, for the purposes of this article, I define the frames utilized by international actors into the following four categories: (1) portrayal of actors; (2) solutions; (3) knowledge; and (4) effective control of implementation processes. ${ }^{3}$

\footnotetext{
${ }^{3}$ For the coding I rely on a simple binary of positive versus negative or international versus domestic. While this-in numeric termssimplifies the complexity, the example text segments provided in the analysis and the ESM add the necessary nuance and transparency.
}

\section{Portrayal of actors}

Given the centrality of actors, their portrayal-that is, how they are described and 'spoken about' in the reports-represents a critical frame. Across the four ideal types of actors, portrayal can be either negative or positive (Table 1). For instance, the portrayal of domestic actors is mainly positive if relevant segments ascribe a degree of agency-in terms of the capacity and skills to act and find solutions-to domestic actors. By contrast, the portrayal is mainly negative if domestic actors are emphasized as being incapable of tackling problems, politically unsuitable (illiberal), and/or conceived as being part of the problem rather than the solution (Scheye and Peake 2005; von Billerbeck 2015).

\section{Solutions}

Solutions-that is, the type of operational policy action to be implemented-are coded as universal versus contextual/ domestic (see Table 1). Where there is a focus on finding contextually appropriate solutions, which consider domestic ecological and social circumstances rather than broad universal blueprints, text segments are coded as contextual/ domestic. By contrast, universal solutions are characterized by a prevalence of technical international solutions, which are considered universally applicable irrespective of contextual factors. Often these are nirvana concepts that offer 'an ideal image of what the world should tend to' (Molle 2008, p. 132), and are conceived as providing some degree universal applicability. Examples include liberal peacebuilding (e.g. Chandler 2006) and Integrated Water Resource Management (Jeffrey and Gearey 2006; Giordano and Shah 2014).

\section{Knowledge}

Knowledge refers to the kind of knowledge that solutions demand, and whose knowledge this is. Often-though not always-solutions and knowledge are connected. Text segments are coded according to whether they stress domestic knowledge- that is, domestic knowledge is privileged as being relevant and unique when it comes to implementing solutions - or international knowledge, according to which solutions require international expert knowledge (Zaum 2007; Chandler 2010) rather than domestic expertise.

\section{Effective control of implementation processes}

Effective control relates to who is the agent in charge of implementing proposed solutions. Coding is again binary (high/low) and is attributed to actor groups (Table 1). Double coding is possible if a solution clearly spells out a partnership between agents. Text segments attributing effective 
Table 2 Metadata for reports

\begin{tabular}{llcr}
\hline Year & Report name & $\begin{array}{l}\text { Length total } \\
\text { (pages) }\end{array}$ & $\begin{array}{l}\text { Length excl. } \\
\text { appendix } \\
\text { (pages) }\end{array}$ \\
\hline 2009 & From Conflict to Peacebuilding: The Role of Natural Resources and the Environment & 50 & 31 \\
$2013 \mathrm{a}$ & Women and Natural Resources: unlocking the Peacebuilding Potential & 74 & 50 \\
$2013 \mathrm{~b}$ & The Role of NATURAL Resources in Disarmament, Demobilization and Reintegration & 72 & 55 \\
2015 & Natural Resources and Conflict: A Guide for Mediation Practitioners & 106 & 57 \\
\hline
\end{tabular}

control mainly to domestic state actors are coded 'domestic state high'. By contrast, segments attributing effective control mainly to international state actors are coded 'international state high'. Keywords in this regard include, for instance, 'require help' or 'need assistance' (e.g. Crawford 2003; Fearon and Laitin 2004).

\section{Qualitative content analysis}

To achieve a more transparent and credible analysis of ownership, I employ Computer-Assisted Qualitative Data Analysis Software (CAQDAS) to code the operationalization of ownership frames in text documents. Qualitative content analysis (QCA) is well-suited to systematically describing and analyzing qualitative data, and in so doing identifying the 'latent and more context-dependent meaning' of documents (Mitchell 1991). To mitigate subjectivity, the QCA follows a sequence of steps (Schreier 2013), which involves a manual coding process complemented by CAQDAS.

First, a coding scheme was developed based on the operationalization of ownership set out above, thereby enabling a systematic, theory-driven coding process. Separating the coding scheme's development from the main analysis is an essential step of QCA, as it allows for structured data analysis and reduces the degree of arbitrary interpretation (Schreier 2013, p. 173).

The coding scheme builds on the operationalization of the ownership concept and is represented in Table 1. To conduct the coding, digital copies of the original reports were entered into MaxQDA, which, in contrast to other software, is designed for deductive, theory-driven data analysis (Lewin and Silver 2007). The software facilitates the management, retrieval and analysis of coded segments, and also compiles quantitative summaries of these segments, thereby providing a holistic picture of the categories within a document. Moreover, by supporting the structured presentation of quantitative and qualitative results it goes beyond other content analysis methods, adding nuance and depth to the quantitative summaries. As the same process was applied to each document, the analysis permits a 'systematic comparison and cumulation of the findings' (George and Bennett 2005, p. 67).

The reports studied in this article represent official UNEP policy and - despite the diversity of topics covered—form a coherent part of a single UNEP project: the Environmental Cooperation for Peacebuilding Programme (2008-2015). Given the reports' high profile as co-authored publications with other UN agencies, they rank higher in agenda-setting importance than, for instance, UNEP field assessments. All four reports underwent extensive internal review and are accessible to the public. In addition, drafts of the reports were made available for review among a multitude of UN actors, as well as UN Member States (United Nations Environment Programme 2009 annex 4). Table 2 lists the reports included in the analysis. The reports 'Protecting the Environment During Armed Conflict: An Inventory and Analysis of International Law' (2009) and 'Greening the Blue Helmets: Environment and Natural Resources in UN Peacekeeping Operations' (2012) have been excluded from analysis, as both fall outside the scope of this study. Only the main text of a report was included in the analysis, with pictures and appendices excluded. Reports will hereafter be referred to by their publication date. Given the differences in report length, frequency is reported in percentages (relative to each report) to allow comparability across documents.

During the coding process, text segments were manually assigned to the coding scheme's preset categories. A coded segment represents a unit of meaning (Schreier 2013) - that is, a sentence or series of sentences in which a particular sentiment or idea is presented. To ensure consistency of coding, the process was repeated on sample sections of the documents (Schreier 2013). Lastly, document summaries were generated in MaxQDA to assess the coding scheme's 'exhaustiveness', thereby ensuring that 'all parts of the material are equally accounted for by the coding frame' (Schreier 2013, p. 175). Across all four reports 1,258 segments were coded-an average of 314.5 segments per report. ${ }^{4}$

\footnotetext{
$\overline{{ }^{4} \text { Range } 204}$ (2009 report) to 438 (2013b).
} 
Fig. 2 Portrayal of actors (all reports, as \%)

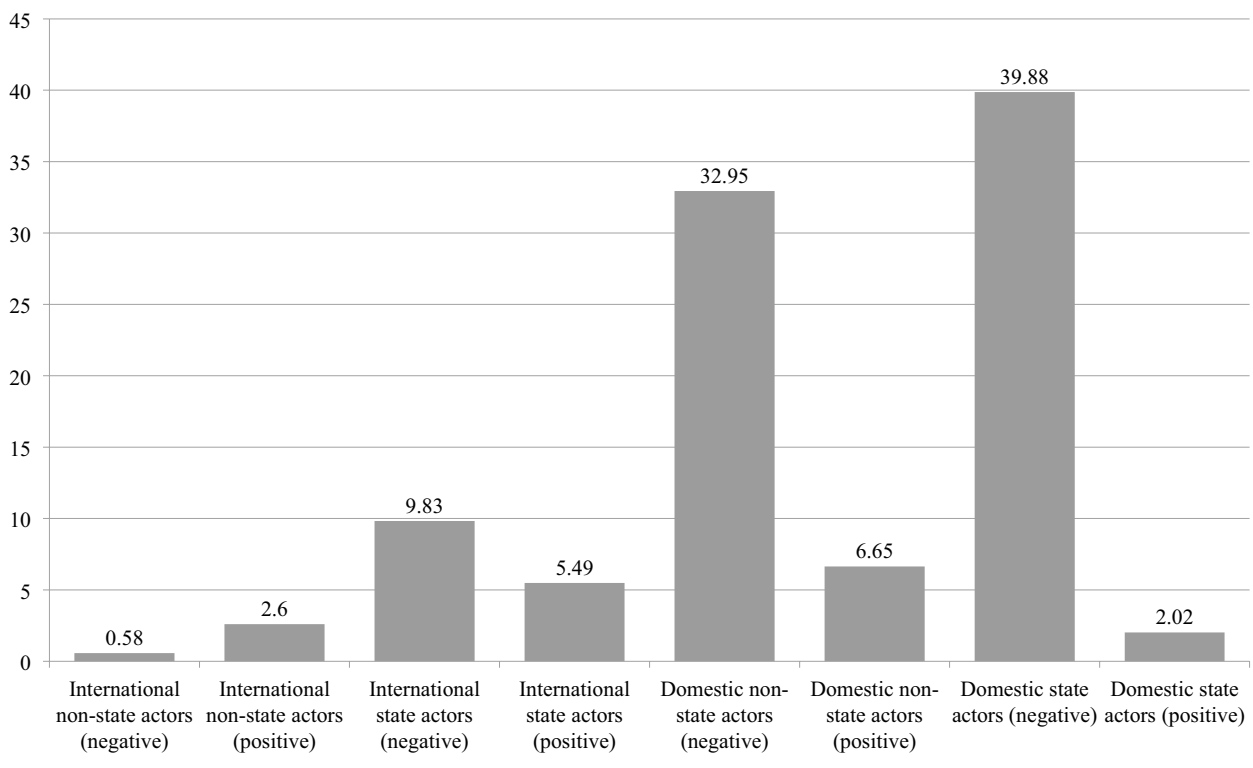

\section{Results of the qualitative content analysis}

The results arising from the QCA offer new insight into the implicit normative content of UNEP's environmental peacebuilding policy framework. However, it should be noted that the results are limited to how the framework is expressed in the documents, and do not necessarily reflect how UNEP operations are conducted in the real world. As anticipated, the policy framework defined by the reports largely stem from a belief that there is a causal relationship between natural resources and armed conflict. Building on this risk perception, all four reports propose that natural resource issues be incorporated into the peacebuilding agenda. The reports do not make a distinction between non-renewable and renewable natural resources, and primarily focus on the intrastate level. In this section, empirical findings are presented according to the four frames that determine ownership of environmental peacebuilding processes: portrayal of actors, solutions, knowledge, and effective control of implementation processes.

\section{Portrayal of actors}

As stressed earlier, the type and portrayal of actors referred to within the policy framework is very important. Here, the findings lead to two important observations, the first being that the main focus of the reports is on domestic actors, both state and non-state. However, these actors are hypothetical, rather than specific actors with the actual agency in a post-conflict context. This leads to the second observation, illustrated in Fig. 2, that domestic state and non-state actors are negatively portrayed in the reports. Domestic non-state actors are portrayed negatively in $33 \%$ of coded segments
$(N=346)$, while domestic state actors are portrayed negatively in $40 \%$ of coded segments.

Table 3 presents percentages showing how different actor groups are portrayed in each of the reports. Across all portrayals (positive and negative) of all actor groups (domestic and international), negative portrayals are overwhelmingly applied to domestic state and non-state actors, with the next most commonly expressed opinion only a third as prevalent. In other words, in $73 \%$ of cases where an opinion is expressed about an actor group, it is a negative opinion about domestic actors. There are, however, a couple of notable caveats within this. The $2013 \mathrm{~b}$ report is the only one where domestic state actors are not the most negatively portrayed actor. Due to the report's focus on disarmament, demobilization and reintegration (DDR), a large number of coded segments deal with armed groups, which may explain why

Table 3 Portrayal of actors (as \%)

\begin{tabular}{|c|c|c|c|c|c|}
\hline & 2009 & $2013 a$ & $2013 b$ & 2015 & Total \\
\hline \multicolumn{6}{|c|}{ International non-state actors } \\
\hline Negative & 0.00 & 0.00 & 0.90 & 1.20 & 0.58 \\
\hline Positive & 0.00 & 5.05 & 3.60 & 0.00 & 2.60 \\
\hline \multicolumn{6}{|c|}{ International state actors } \\
\hline Negative & 16.98 & 15.15 & 5.41 & 4.82 & 9.83 \\
\hline Positive & 5.66 & 3.03 & 10.81 & 1.20 & 5.49 \\
\hline \multicolumn{6}{|c|}{ Domestic non-state actors } \\
\hline Negative & 33.96 & 18.18 & 39.64 & 40.96 & 32.95 \\
\hline Positive & 1.89 & 18.18 & 3.60 & 0.00 & 6.65 \\
\hline \multicolumn{6}{|c|}{ Domestic state actors } \\
\hline Negative & 41.51 & 36.36 & 33.33 & 51.81 & 39.88 \\
\hline Positive & 0.00 & 4.04 & 2.70 & 0.00 & 2.02 \\
\hline$N$ & 53 & 99 & 111 & 83 & 346 \\
\hline
\end{tabular}


$40 \%$ of segments contain negative portrayals of domestic non-state actors, compared to $33 \%$ for domestic state actors. Meanwhile, the 2013a report, which deals with the role of women, has the highest percentage of positive portrayals of domestic non-state actors at $18 \%$ (in the other reports, this percentage ranges between 0 and 3.6\%). This is largely explained by the report's more emancipatory language about enhancing women's capability, whereas the other reports typically highlight domestic non-state actors' lack of capacity.

While these frequencies provide a general summary of the documents, nuances exist as to why and how certain actor groups are portrayed positively or negatively. For example, domestic state actors and institutions are predominantly portrayed as lacking state capacity and/or being corrupt. An example of this can be seen in the 2009 report (for further examples consult the Electronic Supplementary Material (ESM)):

The common trait in these three situations is the inability of weak states to resolve resource-based tensions peacefully and equitably. Indeed, conflict over natural resources and the environment is largely the reflection of a failure of governance or a lack of capacity. As demands for resources continue to grow, this conclusion highlights the need for more effective investment in environmental and natural resource governance.

('From Conflict to Peacebuilding: The Role of Natural Resources and the Environment', 2009, p. 13).

Regarding the negative portrayal of domestic non-state actors, the nuances point toward differing narratives, rather than sentiments. Though this category conflates civilians with armed groups, it is important to emphasize that negative portrayals are not solely applied to the latter-in fact, the analysis shows that both types of non-state actor are portrayed negatively. In terms of armed groups, the negative portrayal is based around a narrative of greed, in which rebels exploit natural resources for personal gain, and to finance continued rebellion. An example of this can be seen in the $2013 \mathrm{~b}$ report (for further examples consult the Electronic Supplementary Material (ESM)):

In such contexts, research suggests that the formation of insurgent armed groups is more likely. This becomes a particular security risk where economically valuable natural resources can be easily obtained by artisanal, high-labour and low-industrial means (termed 'lootable'). Consequently, these resources and their supply chains can be relatively easily co-opted and used to support belligerent activities by armed groups.

('The Role of Natural Resources in Disarmament, Demobilization and Reintegration', 2013b, p. 18).

By contrast, civilians are typically seen as victims of circumstance. Even so, they are portrayed as a problem, as they are exploiting or depleting natural resources due to a lack of
Table 4 Solutions (as \%)

\begin{tabular}{llllll}
\hline & 2009 & $2013 \mathrm{a}$ & $2013 \mathrm{~b}$ & 2015 & Total \\
\hline Universal solutions & 76.79 & 73.40 & 67.44 & 62.50 & 68.55 \\
$\begin{array}{l}\text { Contextual and/or } \\
\text { domestic solutions }\end{array}$ & 23.21 & 26.60 & 32.56 & 37.50 & 31.45 \\
$N$ & 56 & 94 & 129 & 128 & 407 \\
\hline
\end{tabular}

Table 5 Knowledge (as \%)

\begin{tabular}{llllll}
\hline & 2009 & $2013 \mathrm{a}$ & $2013 \mathrm{~b}$ & 2015 & Total \\
\hline International knowledge & 92.31 & 81.48 & 92.11 & 92.31 & 89.74 \\
Domestic knowledge & 7.69 & 18.52 & 7.89 & 7.69 & 10.26 \\
$N$ & 26 & 54 & 76 & 78 & 234 \\
\hline
\end{tabular}

choice or personal skills. An example of this can be seen in the 2015 report (for further examples consult the Electronic Supplementary Material (ESM)):

Training in interest-based negotiation and related technical skills can be an effective way to balance negotiation capacities. This can be particularly important with groups that tend to be socially marginalized, such as indigenous people, women, or youth.

('Natural Resources and Conflict: A Guide for Mediation Practitioners', 2015, p. 33).

\section{Solutions and knowledge}

The analysis aimed to identify the types of solutions proposed in the reports. Are these universal solutions potentially applicable in every case, or are they contextual solutions that emphasize context-specific circumstances? To deepen understanding of the proposed policies' implicit normative content, the analysis mapped the knowledge source required to support the solutions. Whether such knowledge is deemed domestic or international provides an indication of perceived power relations between actors. Looking at the results, three important observations arise: (1) universal solutions and international knowledge dominate; (2) domestic knowledge plays a subordinate role; and (3) context matters, but only to a limited degree.

Table 4 presents the types of solutions featured in the reports. More than 69 percent of coded segments propose universal solutions, ranging between 62.5 and $76.79 \%$ across the reports. This variation between reports reveals a small, yet interesting, development, with the $2013 \mathrm{~b}$ and the 2015 reports showing a lower number of universal solutions compared to the 2009 and 2013a reports, which show a higher frequency of contextual and/or domestic solutions. However, when these results are compared with those for knowledge (Table 5), it becomes clear that 
Table 6 Co-occurrences of coded segments showing intersections/ overlap (as \% among all documents)

\begin{tabular}{ll} 
Knowledge & \\
\hline $\begin{array}{l}\text { Domestic knowledge } \\
(\%)\end{array}$ & $\begin{array}{l}\text { International } \\
\text { knowledge } \\
(\%)\end{array}$ \\
\hline
\end{tabular}

Solutions

\begin{tabular}{lll}
$\begin{array}{l}\text { Contextual and/or domestic } \\
\text { solutions }\end{array}$ & 4 & 28 \\
Universal solutions & 2.4 & 53.6 \\
& $N=248$ & \\
\hline
\end{tabular}

this increased focus on context does not signify increased appreciation of domestic knowledge. Rather, the contrary appears true, as the $2013 \mathrm{~b}$ and 2015 reports show greater reference to international knowledge than 2009 and 2013a. Closer inspection reveals this emphasis on context is due to the role of various natural resources, with domestic knowledge apparently not considered relevant when it comes to addressing these issues. Instead, the majority of segments address international expert knowledge. The perceived importance of international knowledge in the environmental peacebuilding framework is illustrated in Table 5, with $90 \%$ of all coded segments referencing such knowledge, compared to only $10 \%$ for domestic knowledge. In the 2009, 2013b and 2015 reports, this figure is even lower, at just above $7.5 \%$.

Nevertheless, comparing the reports does reveal relevant differences. Of the four, the 2013a report has the highest representation of domestic knowledge. Overall, it appears that the focus on women as domestic actors exerts a strong influence on the policy framework's shape, resulting in the potential of domestic non-state actors being emphasized more than is the case for the other reports:

At the local level, in particular, the knowledge and experience women may have of a particular natural resource due to their roles and responsibilities can provide a clear entry point to involve them in decision-making processes. In the Iraqi marshlands, for example, male leaders have welcomed women's participation in deciding how to manage local water resources.

('Women and Natural Resources: Unlocking the Peacebuilding Potential', 2013a, p. 35).

This emphasis is not confined to female-specific knowledge, but 'due to the gender-specific roles in forestry, both women and men possess unique knowledge and skills that, if properly tapped into during DDR programmes, can create productive, comprehensive and environmentally sound new livelihoods in the forestry sector' ('The Role of Natural Resources in Disarmament, Demobilization and Reintegration', 2013b, page 40). However, it does not appear that this emphasis on domestic knowledge had any substantial impact
Table 7 Control of implementation processes (as \%)

\begin{tabular}{llllll}
\hline & 2009 & $2013 \mathrm{a}$ & $2013 \mathrm{~b}$ & 2015 & Total \\
\hline International non-state actors & 0.00 & 4.17 & 1.54 & 0.00 & 1.63 \\
International state actors & 72.22 & 58.33 & 66.15 & 67.92 & 65.22 \\
Domestic non-state actors & 5.56 & 20.83 & 15.38 & 16.98 & 16.30 \\
Domestic state actors & 22.22 & 16.67 & 16.92 & 15.09 & 16.85 \\
$N$ & 18 & 48 & 65 & 53 & 184 \\
\hline
\end{tabular}

on later reports, albeit references to the role of women appear more frequently.

Throughout the reports, a clear link exists between universal solutions and international knowledge. This becomes evident when looking at instances where coded segments overlap-that is, when two codes appear in the same location (typically the same paragraph), as presented in Table 6 .

Looking at the co-occurrence of solutions and knowledge-that is, when they appear within the same coded segment $-54 \%$ of such instances pair universal solutions with international knowledge. This suggests that international ownership represents a significant dimension of UNEP's environmental peacebuilding framework. This assessment is strengthened by the fact that while $28 \%$ of contextual and/ or domestic solutions overlap with international knowledge, only $4 \%$ of such contextual solutions utilize domestic knowledge. This trend is consistent throughout the documents, with international knowledge considered critical to $82 \%$ of all proposed solutions.

These results suggest that although the environmental peacebuilding framework considers context to be relevant, international expertise is considered necessary irrespective of the solution. For example, while assessments of natural resource bases emphasize the specific context of each case, the solutions on offer remain highly technical, and thus demand international expert involvement (see 'The Role of Natural Resources in Disarmament, Demobilization and Reintegration', 2013b, p. 11).

This finding is consistent with previous research on environmental peacebuilding, as well as broader intervention practice, which historically has tended to favor technical, expert-driven solutions (Aggestam and Sundell-Eklund 2013; Krampe 2016; Ide 2020).

\section{Control of implementation processes}

Proposals for concrete action were coded according to the level of control (high/low) attributed to an actor group. This is an important indicator, as it suggests who is actually in charge of policy processes. The results presented in Table 7 suggest that relatively little control is assigned to non-state actors, either domestic or international. By contrast, control is overwhelmingly assigned to international state actors 
(65\%), which to some degree might be expect given that UNEP and other UN actors can be assumed to be a key audience for the reports. Yet, this category has the lowest number of coded segments (184 across all reports), which indicates that the reports devote relatively little space to concrete proposals. One explanation for this may be that-as suggested by research on the language used by the World Bank (Moretti and Pestre 2015; Felli 2016)—international organizations tend to use the passive form to avoid questions of ownership. Moreover, this perhaps correlates with the emphasis on universal solutions.

As with the other categories of analysis, the control of implementation processes frame reveals notable variations between the reports. First, while the 2013a report-as is the case for all four reports-assigns the greatest amount of control to international state actors (relative to the other three actor groups), domestic non-state actors here receive the highest percentage seen across the reports ( $21 \%$ of coded segments). This is due to the 2013a report's emphasis on the inclusion of women as actors in peacebuilding processes. For example:

including women in the design and implementation of new water infrastructure can yield improved results in effectiveness and use. Research shows that in cases where women and men are equally consulted in terms of location and placement of water and sanitation infrastructure, the installations are more frequented, better maintained and technically appropriate. ('Women and Natural Resources: Unlocking the Peacebuilding Potential', 2013a, p. 25).

Second, contrary to what might be expected based on findings from the previous categories, domestic actors are perceived to play a more important and slightly more comprehensive role. In particular, the increased relevance of domestic non-state actors is a noteworthy observation.

However, a closer examination of this category's cooccurrences reveals a more complex picture. Looking at the absolute number of coded segments, it can be seen that of the 29 segments that assign high control to domestic state actors, 19 also suggest control by international state actors. Thus, while the reports indicate that domestic actors should be involved in the peacebuilding process, the co-occurrences suggest that international guidance for domestic state actors is often expected. An example of this can be seen in the 2009 report (for further examples consult the Electronic Supplementary Material (ESM)):

The international community should be prepared to help national authorities manage the extraction process and revenues in ways that do not increase the risk of further conflict or are unsustainable in the longer term. This must go hand in hand with ensuring accountability, transparency and environmental sustainability in their management.

('Conflict to Peacebuilding: The Role of Natural Resources and the Environment', 2009, p. 29).
By comparison, for domestic non-state actors, just seven of 27 segments assign shared control. Interestingly, despite domestic control being identified as the main relationship of interest in peacebuilding, only four segments across all the reports assign control solely to domestic state and non-state actors together.

\section{Discussion}

The analysis above provides new insight into the subjective content of UNEP reports, which are part of the Environmental Cooperation for Peacebuilding Programme, especially regarding questions of ownership and the roles played by various actor groups. While we might expect these reports to affect policy action, it does not necessarily follow that their contents are reflective of actual UNEP operations on the ground. ${ }^{5}$ Yet, given the literature showing how policy frames influence actors' behavior and decision-making, the following section offers an opportunity to engage with the results' implications.

The results indicate that UNEP reports focus mainly on international ownership when outlining strategies aimed at achieving sustainable management of natural resources in post-conflict settings. Per the definition presented earlier, a characteristic of international ownership is the negative portrayal of domestic actors. Across all the reports, $73 \%$ of coded segments involve negative portrayals of domestic state and non-state actors. In addition, international ownership emphasizes international technical solutions, which are treated as universally applicable. Universal solutions dominate the sample (69\% of segments), while international knowledge is referenced in $90 \%$ of coded segments in the solutions category. Lastly, in $65 \%$ of segments coded as effective control of implementation processes, control of environmental peacebuilding polices is assigned to international state actors.

The above analysis sheds surprising light on the role of different actors in environmental peacebuilding, most notably the absence of international non-state actors, who are considered to have effective control in less than $2 \%$ of coded segments. This is startling, given the significance of international non-state actors-particularly international environmental NGOs-for global environmental governance. Instead, the ownership frames clearly depict international state actors as the most dominant type of actor, assigning them control of environmental peacebuilding policies four times more often than is the case for domestic actors. In light

\footnotetext{
${ }^{5}$ Regarding the tension between international mandate and local needs that peacebuilding actors often experience, see Campbell (2019).
} 
of this evidence, I now discuss how these frames relate to questions of ownership, and in turn environmental peacebuilding practice.

\section{Implications of a focus on international ownership}

If, as many scholars and practitioners do, we consider domestic ownership key to the success of peace processes (Donais 2009), then the environmental peacebuilding framework's strong focus on international ownership is cause for concern. In particular, two ownership frames evident in the reports may hinder domestic actors' involvement and agency: first, a tendency to assign responsibility for causing and perpetuating resource-induced conflict to domestic actors; and, second, a preference for universal solutions and international knowledge over domestic solutions.

The first implication relates to the negative portrayal of domestic actors. All four reports portray domestic actors negatively while devoting a considerable number of pages (typically one chapter) to outlining the link between natural resources and conflict. These sections conflate renewable and non-renewable resources, despite the scientific evidence presenting a more nuanced story regarding the risks posed by natural resources (see e.g. Berdal 2005; Koubi et al. 2014). Moreover, the reports attribute responsibility for the risk of resource-induced conflict to domestic state and nonstate actors, portraying them as lacking necessary capacity and skills, or as greedy opportunists willing to exploit natural resources for personal or rebellious gain.

While it is conceivable that readers of these reports will not be affected by these messages (or are able to contextualize them), there are several reasons why negative effects on the inclusion of domestic actors may be anticipated. Take, for instance, pre-deployment training. Here, negative portrayals of domestic actors may plant seeds of distrust between international and domestic actors, while feeding negative perceptions of the latter. Given such distrust and negative perceptions, it may be inferred that peacebuilding actors in search of solutions and expertise are more likely to rely on international actors. This makes the exclusion of domestic actors, solutions and expertise all the more likely. The widely established relevance of cognitive frames on individual decision-making adds theoretical validity to this claim (Haas 1992; Finnemore and Sikkink 1998; Molle 2008). Indeed, social psychology research suggests that under stressful situations, individuals tend to fall back on existing cognitive frames. This leads to predictable, safe and generalized decisions, thereby facilitating the decision-making process (Staal 2004; Bar-Tal and Halperin 2011). In the context of peacebuilding missions, it may be assumed that involved actors-especially international staff, but potentially also internationally trained domestic actors-rely heavily on their training as a guide for action, and therefore favor international ownership (Autesserre 2009). Thus, the prevalence of universal solutions and international knowledge in the UNEP reports is likely to further consolidate cognitive schemes that favor international ownership, in turn discouraging domestic involvement.

The second implication stems from the prominence of universal solutions and international knowledge, with all four reports giving the impression that successful environmental peacebuilding is best conducted using international technical expertise. This point is stressed on a number of occasions, as can be seen in this example from the 2015 report:

Mediator expertise on natural resource issues: Broadly speaking, there are two options for selecting mediators for natural resource disputes. One involves appointing a mediator with limited knowledge of natural resources while relying on a technical support team of natural resource specialists. The other involves a mediator with a solid technical background on natural resource-related issues, perhaps supported by other mediators. Determining the mediator(s) and other support experts required for a mediation process is tied directly to the complexity of the dispute as well as the objectives of the mediation and the needs of the parties.

('Natural Resources and Conflict: A Guide for Mediation Practitioners', 2015, p. 13).

While a technical approach has merit and will likely provide operational efficiency in the use of natural resources, the emphasis on international expert knowledge neglects the inherently political dimensions of the problems at hand. In the foreword to the 2015 report, UN Deputy SecretaryGeneral Jan Eliasson states:

Yet to date, the role mediation can play in peacefully resolving conflicts over natural resources has not been examined in a systematic way. Furthermore, mediators unfamiliar with the issues may be tempted to consider them as largely technical, thereby not fully appreciating their political nature and strategic importance. A challenge, therefore, is to ensure that mediators are fully equipped to grapple with the many complex issues involved.

('Natural Resources and Conflict: A Guide for Mediation Practitioners', 2015, p. 5).

The report does go on to explicitly state that 'resource disputes are inherently political, in that they feed into power disparities among various players. Accordingly, any comprehensive attempt at conflict resolution must take into account the political context of the conflict along with its technical dimensions' (2015, p. 7). Even so, the reports do not accentuate the political context, thereby implying a lack of faith in domestic political solutions. In addition, treating issues as being purely technical serves to depoliticize them, rather than desecuritizing them (Aggestam 2015). Moreover, previous research suggests that portraying issues as purely technical can have negative implications for domestic ownership 
of peacebuilding processes (Zaum 2007; Tadjbakhsh 2011), and environmental peacebuilding in particular (Aggestam and Sundell-Eklund 2013; Hanasz 2015). This is because a focus on international knowledge places ownership in the hands of international experts and technocrats, disempowering domestic actors who might otherwise be able to contribute to the sustainable domestic management of conflict (Krampe 2016).

These implications should be seen with caution and require further study, given the narrow focus of this study on the four key reports of the four core reports of the United Nations Environment Programme (UNEP)'s Environmental Cooperation for Peacebuilding Programme. However, based on the current state of knowledge regarding peacebuilding and peace operations (Winslow 1997; Coles 2011; Autesserre 2014), as well as international norms diffusion (Finnemore and Sikkink 1998) and social psychology (Staal 2004; BarTal and Halperin 2011), there are strong reasons to anticipate that the current environmental peacebuilding policy framework disfavors domestic actors' involvement and agency.

\section{The importance of context and a positive narrative}

Irrespective of the international ownership favored in the reports, two features can be observed that point toward how domestic actors may be empowered in environmental peacebuilding. First, contextual solutions offer a possible pathway to handing over control to domestic actors and benefiting from their knowledge. Contextual solutions appear most often when the focus is on a specific type of natural resource, and are particularly salient in the last two reports (2013b and 2015). However, the current policy framework fails to engage domestic actors, which is surprising given that domestic agency and knowledge has been found to generate more sustainable and legitimate results (Campbell 2019).

Moreover, the 2013a report ('Women and Natural Resources') makes the case for involving domestic actors as a means of strengthening peacebuilding. Though this is partly due to the report's emphasis on the role of women, it is mainly down to the narrative presented. As my analysis demonstrates, the report portrays domestic non-state actors in a positive way six times more often than the other reports. It also refers to domestic knowledge twice as often-both gender-specific knowledge brought by women to the peacebuilding process and women's insights into the management of natural resources. If we consider the effects of cognitive frames as valid, then a more positive narrative about the capacity and skills of domestic actors can potentially impact how peacebuilding practitioners perceive and interact with them. In other words, by absorbing reports that portray domestic actors positively, peacebuilders are more likely to recognize the relevance of domestic involvement in peacebuilding processes.

\section{Conclusion}

This article has explored how we can empirically examine non-state roles in reports published as part of UNEP's Environmental Cooperation for Peacebuilding Programme (2008-2015). More explicitly, it has interrogated understandings of why and how non-state actors are/are not being engaged as meaningful partners. By establishing indicators for ownership frames, and disaggregating actor groups into four categories, the analysis has illustratedvia the example of the UNEP-which actor groups are perceived to hold ownership over environmental peacebuilding processes. The analysis attests to the fact that, in addition to an explicit focus on environmental issues, the environmental peacebuilding framework contains strong policy frames on ownership.

Given the relevance of (both domestic and international) non-state actors in shaping the environmental discourse and international politics, it may be anticipated that they would play a dominant role in the environmental peacebuilding framework. The analysis, however, reveals that these actors are widely absent from the policy framework. In light of this, important questions arise not only regarding UNEP's environmental peacebuilding practice but wider UN action around natural resource management in conflict-affected settings. Specifically, the use of these reports as training material for UNEP and other UN staff may discourage practitioners from involving domestic state and non-state actors, and as such potentially inhibits sustainable management of resources, as well as impacting wider peacebuilding efforts.

To better understand how pathways toward a more sustainable and peaceful global society can be achieved, future research should, first, further trace the origins of the discovered policy frames. Here, the work of Conca (2015) provides an important entry point, though future research needs to be more explicitly centered on environmental peacebuilding. Second, future research must empirically test the influence of environmental peacebuilding frameworks on the perceptions and practices of peacebuilding staff. The work of Autesserre (2014), among others, provides a clear methodological and theoretical pathway to such research.

Supplementary Information The online version contains supplementary material available at https://doi.org/10.1007/s11625-021-00926-x.

Open Access This article is licensed under a Creative Commons Attribution 4.0 International License, which permits use, sharing, adaptation, distribution and reproduction in any medium or format, as long as you give appropriate credit to the original author(s) and the source, provide a link to the Creative Commons licence, and indicate if changes were made. The images or other third party material in this article are included in the article's Creative Commons licence, unless indicated otherwise in a credit line to the material. If material is not included in the article's Creative Commons licence and your intended use is not 
permitted by statutory regulation or exceeds the permitted use, you will need to obtain permission directly from the copyright holder. To view a copy of this licence, visit http://creativecommons.org/licenses/by/4.0/.

\section{References}

Aggestam K (2015) Desecuritisation of water and the technocratic turn in peacebuilding. Int Environ Agreem 15:327-340. https ://doi.org/10.1007/s10784-015-9281-x

Aggestam K, Sundell-Eklund A (2013) Situating water in peacebuilding: revisiting the Middle East peace process. Water Int 39:10-22. https://doi.org/10.1080/02508060.2013.848313

Albin C (1999) Can NGOs enhance the effectiveness of international negotiation? Int Negot 4:371-387. https://doi. org/10.1163/15718069920848534

Autesserre S (2009) Hobbes and the Congo: frames, local violence, and international intervention. Int Organ 63:249. https://doi. org/10.1017/S0020818309090080

Autesserre S (2014) Peaceland. Cambridge University Press, New York

Barma NH (2016) The Peacebuilding Puzzle: political order in Post-Conflict States. In: Cambridge Core. https://www.cambr idge.org/core/books/peacebuilding-puzzle/155E4450DEEE853 3AADA45F659E6A0A6. Accessed 24 Nov 2020

Bar-Tal D, Halperin E (2011) Socio-psychological barriers to conflict resolution. Psychology Press, New York, pp 217-240

Berdal M (2005) Beyond greed and grievance: and not too soon.... Rev Int Stud 31:687. https://doi.org/10.1017/s0260210505006698

Bernauer T, Böhmelt T, Koubi V (2013) Is there a democracy-civil society paradox in global environmental governance? Glob Environ Politics 13:88-107

Campbell S (2019) Global Governance and Local Peace: accountability and performance in international peacebuilding. Cambridge University Press, Cambridge

Chandler D (2006) Empire in denial: the politics of state-building. Pluto Press, London

Chandler D (2010) International Statebuilding: the rise of post-liberal governance. Taylor \& Francis, London

Chesterman S (2007) Ownership in theory and in practice: transfer of authority in UN statebuilding operations. J Interv Statebuilding 1:3-26

Coles K (2011) Democratic designs: international intervention and electoral practices in Postwar Bosnia-Herzegovina. University of Michigan Press, Ann Arbor, pp 1-315

Collier P, Hoeffler A (2000) Greed and grievance in civil war. The World Bank, Washington, DC

Conca K (2015) An unfinished foundation. Oxford University Press, Oxford

Conca K, Dabelko G (2002) Environmental peacemaking. The Johns Hopkins University Press, Washington, DC

Crawford G (2003) Partnership or power? Deconstructing the partnership for governance reform in Indonesia. Third World Q 24:139-159

Dabelko G, Herzer L, Null S et al (2013) Backdraft: the conflict potential of climate change adaptation and mitigation. Environmental Change and Security Program. Wilson Center, Washington, DC

Donais T (2008) Local ownership and security sector reform. LIT Verlag, Muenster

Donais T (2009) Empowerment or imposition? Dilemmas of local ownership in post-conflict peacebuilding processes. Peace Change 34:3-26

Donais T (2012) Peacebuilding and local ownership. Routledge, London
Fearon JD, Laitin DD (2004) Neotrusteeship and the problem of weak states. Int Secur 28:5-43. https://doi.org/10.1162/01622 88041588296

Felli R (2016) The World Bank's neoliberal language of resilience. In Risking capitalism. Emerald Group Publishing Limited, Bingley, pp 267-295

Finnemore M (2006) The purpose of intervention: changing beliefs about the use of force. Cornell University Press, Ithaca

Finnemore M, Sikkink K (1998) International norm dynamics and political change. Int Organ 52:887-917. https://doi. org/10.1162/002081898550789

Gemmill B, Bamidele-Izu A (2002) The Role of NGOs and Civil Society in Global Environmental Governance. Glob Environ Govern Options 77-100

George AL, Bennett A (2005) Case studies and theory development in the social sciences. MIT Press, Cambridge

Giordano M, Shah T (2014) From IWRM back to integrated water resources management. Int J Water Resour Dev 30:364-376. https://doi.org/10.1080/07900627.2013.851521

Haas PM (1992) Introduction: epistemic communities and international policy coordination. Int Organ 46:1-35

Haas PM, Keohane RO, Levy MA (1993) Institutions for the Earth. MIT Press, Cambridge

Hanasz P (2015) Upside down and inside out. Wiley, New York

Höglund K, Orjuela C (2013) Friction and the pursuit of justice in post-war Sri Lanka. Peacebuilding 1:300-316. https://doi. org/10.1080/21647259.2013.813171

Ide T (2018) Does environmental peacemaking between states work? Insights on cooperative environmental agreements and reconciliation in international rivalries. J Peace Res 14:002234331775021. https://doi.org/10.1177/0022343317 750216

Ide T (2020) The dark side of environmental peacebuilding. World Dev 127:104777. https://doi.org/10.1016/j.worlddev.2019.104777

Ivanova M (2010) UNEP in global environmental governance: design, leadership, location. Glob Environ Politics 10:30-59

Jarstad AK, Olsson L (2012) Hybrid peace ownership in Afghanistan: international perspectives of who owns what and when. Glob Gov 18:105-119

Jasanoff S (2004) States of knowledge. Routledge, London

Jeffrey P, Gearey M (2006) Integrated water resources management: lost on the road from ambition to realisation? Water Sci Technol $53: 1-8$

Johnson MF (2019) Strong (green) institutions in weak states: environmental governance and human (in) security in the Global South. World Dev 122:433-445. https://doi.org/10.1016/j.world dev.2019.06.010

Johnson MF, Luz AR, Manuela QH (2021) Intrastate environmental peacebuilding: a review of the literature. World Dev 137: 105150. https://doi.org/10.1016/j.worlddev.2020.105150

Kabeer N (1999) Resources, agency, achievements: reflections on the measurement of women empowerment. Dev Change 30:435-464. https://doi.org/10.1111/1467-7660.00125

Koubi V, Spilker G, Böhmelt T, Bernauer T (2014) Do natural resources matter for interstate and intrastate armed conflict? $\mathrm{J}$ Peace Re 51:227-243. https://doi.org/10.1177/002234331349345 5

Kovach T, Conca K (2016) Environmental priorities in post-conflict recovery: efficacy of the needs-assessment process. J Peacebuilding Dev 11:4-24. https://doi.org/10.1080/15423166.2016.11810 02

Krampe F (2016) Water for peace? Post-conflict water resource management in Kosovo. Coop Confl. https://doi.org/10.1177/00108 36716652428 
Krampe F (2017) Toward sustainable peace: a new research agenda for post-conflict natural resource management. Glob Environ Politics 17:1-8. https://doi.org/10.1162/GLEP_a_00431

Krampe F, Ekman L (2020) Post-war legitimacy: a framework of relational agency in peacebuilding. In: Richmond OP, Mac Ginty R (eds) Local legitimacy and international peacebuilding. Edinburgh University Press, Edinburgh

Krampe F, Swain A (2021) Environmental peacebuilding. In: Richmond OP, Visoka G (eds) The Oxford handbook of peacebuilding, statebuilding, and peace formation. Oxford University Press, Oxford

Krampe F, Wirkus L, Swatuk LA (2018) Countering the boomerang effect in fragile and conflict-affected states. Elgar, Bonn

Le Billon P (2001) The political ecology of war: natural resources and armed conflicts. Political Geogr 20:561-584. https://doi. org/10.1016/S0962-6298(01)00015-4

Lederach JP (1997) Building peace—sustainable reconciliation in divided societies. United States Institute of Peace Press, Washington, DC

Lee SY, Özerdem A (2015) Local ownership in international peacebuilding: key theoretical and practical issues. Routledge, London

Lewin A, Silver C (2007) Using software in qualitative research. SAGE, London

Maertens L (2018) Depoliticisation as a securitising move: the case of the united nations environment programme. Euro J Int Sec 3:344-63. https://doi.org/10.1017/eis.2018.5

Mason M (2014) Climate insecurity in (post) conflict areas: the biopolitics of United Nations vulnerability assessments. Geopolitics 19:806-828. https://doi.org/10.1080/14650045.2014.903393

Migdal JS (2001) State in society. Cambridge University Press, Cambridge

Migdal JS (2004) Boundaries and belonging. Cambridge University Press, Cambridge

Mitchell T (1991) The limits of the state: beyond statist approaches and their critics. Am Political Sci Rev 85:77. https://doi. org/10.2307/1962879

Molle F (2008) Nirvana concepts, narratives and policy models: insights from the water sector. Water Alternatives

Moretti F, Pestre D (2015) Bankspeak: the language of World Bank reports. New Left Rev 92:75-99

Murdie A, Urpelainen J (2015) Why pick on us? Environmental INGOs and state shaming as a strategic substitute. Political Stud 63:353372. https://doi.org/10.1111/1467-9248.12101

Najam A (2003) The case against a new international environmental organization. Glob Gov Rev Multilater Int Organ 9:367-384. https ://doi.org/10.1163/19426720-00903008

O’Neill K, Balsiger J, VanDeveer SD (2004) Actors, norms, and impact: recent international cooperation theory and the influence of the agent-structure debate. Annu Rev Polit Sci 7:149-175
Paffenholz T (2010) Civil society and peacebuilding: a critical assessment. Lynne Rienner Publishers, Boulder

Park S (2005) How transnational environmental advocacy networks socialize international financial institutions: a case study of the International Finance Corporation. Glob Environ Politics 5:95-119

Richmond OP (2013) Failed statebuilding versus peace formation. Cooperation Conflict 48:378-400. https://doi.org/10.1177/00108 36713482816

Roger C, Dauvergne P (2016) The rise of transnational governance as a field of study. Int Stud Rev. https://doi.org/10.1093/isr/viw001

Scheye E, Peake G (2005) Unknotting local ownership. In: Ebnöther AH, Fluri PH (eds) Bureau for Security Policy at the Austrian Ministry of Defence. National Defence Academy, Vienna, pp 235-260

Schreier M (2013) Qualitative content analysis. SAGE, London, pp $170-183$

Söderström J, Åkebo M, Jarstad AK (2020) Friends, fellows, and foes: a new framework for studying relational peace. Int Stud Rev. https ://doi.org/10.1093/isr/viaa033

Staal MA (2004) Stress, cognition, and human performance: a literature review and conceptual framework. In: NASA technical memorandum

Susskind LE, Ali SH (2014) Environmental diplomacy: negotiating more effective global agreements. Oxford University Press, Oxford

Tadjbakhsh S (2011) Rethinking the liberal peace. Taylor \& Francis, London

UNEP (2012) Greening the blue helmets: environment, natural resources and UN peacekeeping operations. UNEP, Washington, DC

Virji H, Sharifi A, Kaneko S, Simangan D (2019) The sustainabilitypeace nexus in the context of global change. Sustain Sci 14:14671468. https://doi.org/10.1007/s11625-019-00737-1

von Billerbeck SBK (2015) Local ownership and UN peacebuilding: discourse versus operationalization. Glob Gov 21:299

Wendt A (1999) Social theory of international politics. Cambridge University Press, Cambridge

Winslow D (1997) The Canadian airborne regiment in Somalia. Canadian Government Publication Centre, Ottawa

Zaum D (2007) Sovereignty paradox: the norms and politics of international statebuilding. Oxford University Press, Oxford

Publisher's Note Springer Nature remains neutral with regard to jurisdictional claims in published maps and institutional affiliations. 